October 2001

Volume 116 Number 5

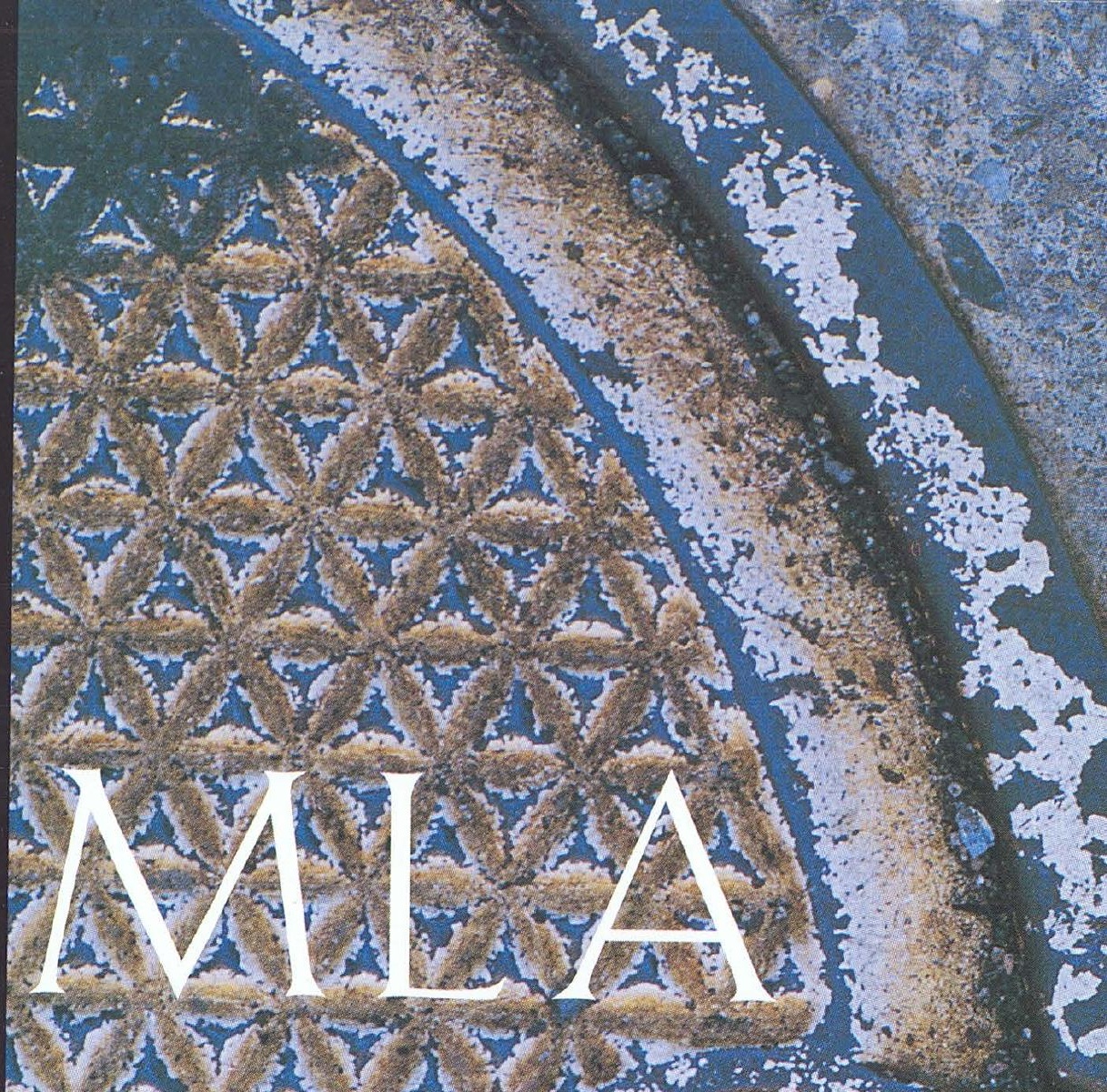

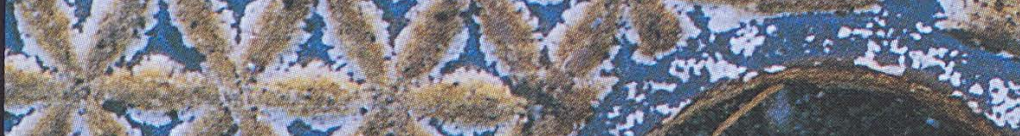

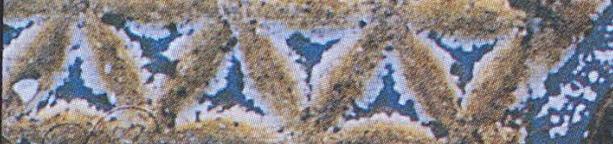

Wr 3 Tra

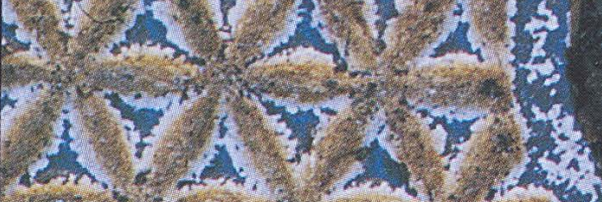

$\cos 2 \cos$

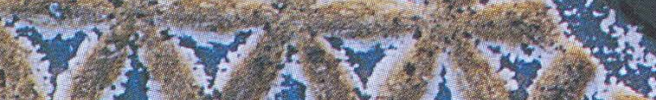

$147272:$

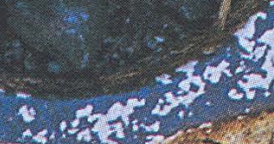

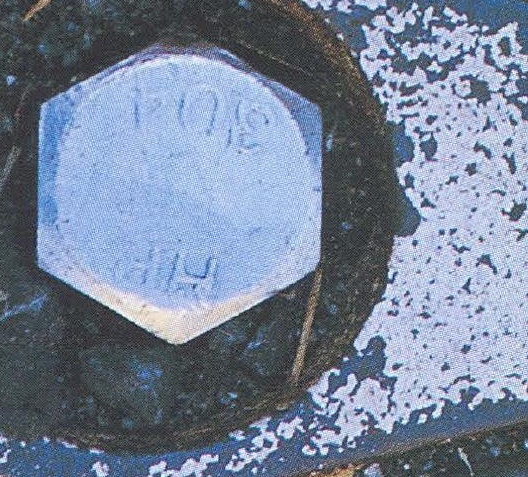

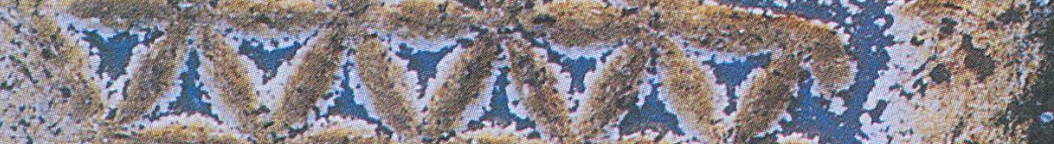

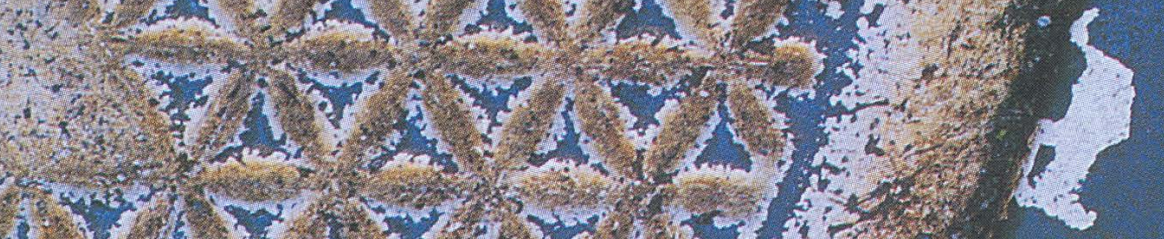

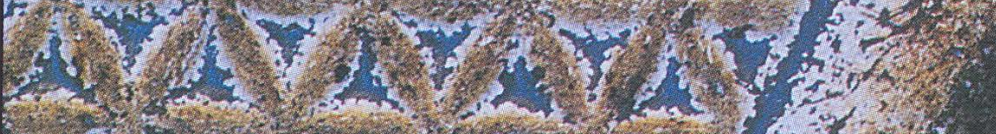

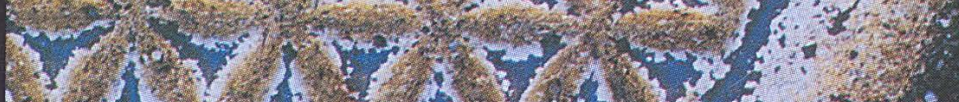

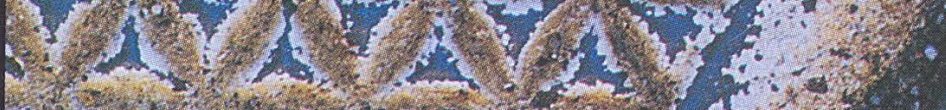

T.

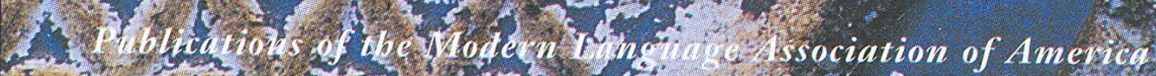

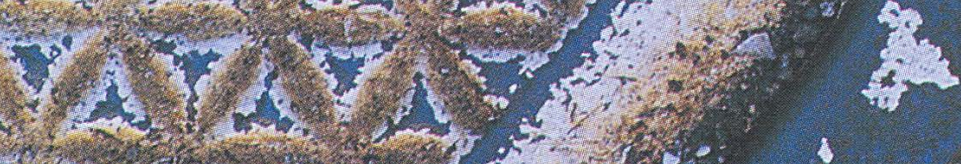

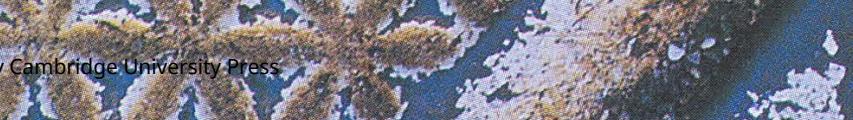




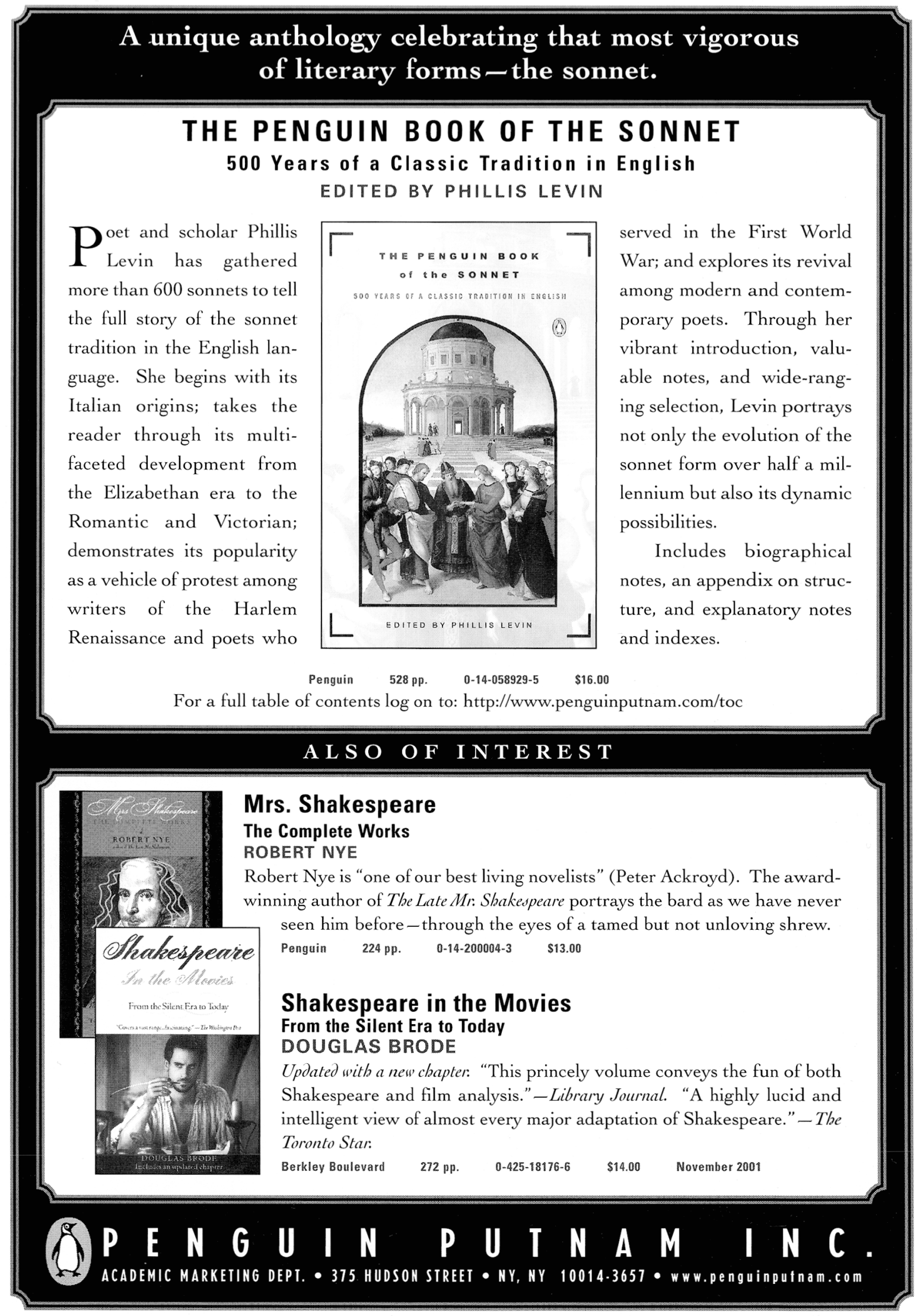




\section{October 2001}

Volume 116 Number 5

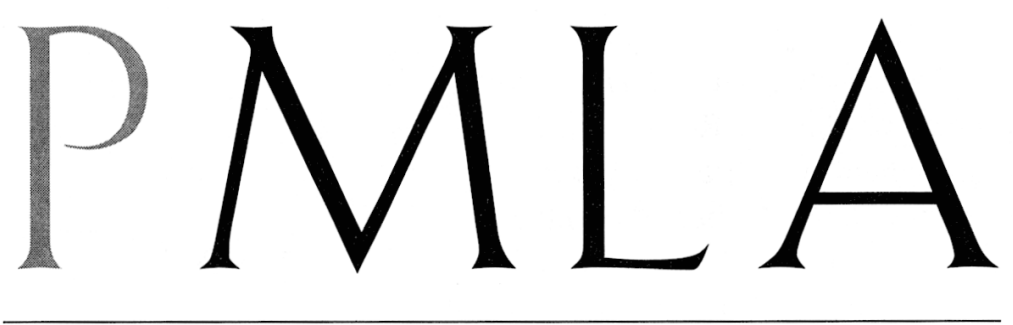

Publications of the Modern Language Association of America 


\section{THE MOdern LanGuage} ASSOCIATION OF AMERICA

Organized 1883 , Incorporated 1900

\section{Officers for the Year 2001}

\section{President: Sylvia Molioy} New York University

First Vice President: Stephen Grel:Nhi.ATt Harvard University

Second Vice President: Mary louisi: PRATT Stanford University

Executive Director: Phyl.Lis Franki.jn

\section{Executive Council}

For the term ending 31 DeCember 2001

DAvid Bartholomal: University of Pittsburgh, Pittsburgh

Kirsten M. Christensen University of Notre Dame Virginia Wright WeXman University of llinois. Chicago ANTHONY C. Yu

University of Chicago

FOR THE TERM ENDING 31 DECEMBER 2002

Roland GREene

Stanford University

FRANŞOISE LIONNET

University of California, Los Angeles

CARY NeLson

University of Illinois, Urbana

FOR THE TERM ENDING 31 DECEMBER 2003

REED WAY DASENBrock

University of New Mexico, Albuquerque

Rosemarie SCUli.ion

University of lowa

Sidonie SMITH

University of Michigan, Ann Arbor

Katie Trumpener

University of Chicago

FOR THE TERM ENDING 31 DECEMBER 2004 JUDITH BUTLER

University of California, Berkeley

Rey CHOW

Brown University

Tey Diana Rebolledo

University of New Mexico. Albuquerque

\section{Trustees of Invested Funds}

JOHN H. D'ARMS

New York, New York

Carolyn G. Heilbrun

New York, New York

Malcolm B. Smith (Managing Trustee) New York, New York
PMLA (ISSN 0030-8129) is published six times a year, in January, March, May, September, Octoher, and November, by the Modern Language Association of America. Membership in the association is open to persons who are professionally interested in the modern languages and literatures. Annual (calendar-ycar) dues, which include subscription to PMLA, are based on members' incomes and are graduated as follows: studem members (seven years maximum), $\$ 20$; new regular members (first year). $\$ 35$; regular members (income under $\$ 15,000$ ), $\$ 25$; regular members (income $\$ 15,000-\$ 20,000)$ ), $\$ 40$ ) regular members (income $\$ 20,000$ $\$ 30,000), \$ 50$; regular members (income $\$ 30,000-\$ 40,000)$, $\$ 65$; regular members (income $\$ 40,000)-\$ 50,0(0)$ ), $\$ 75$; regular members (income $\$ 50,000-\$ 60,000$ ), $\$ 85$; regular members (income $\$ 60,000-\$ 70,000), \$ 15$ : regular members (income $\$ 70,000-\$ 80,000$ ), $\$ 105$; regular members (income $\$ 80,000-\$ 100,000)$ ), $\$ 125$; regular members (income $\$ 100,000-\$ 120,000$ ), $\$ 145$; regular members (income $\$ 120,000-\$ 140,000$ ), $\$ 165$; regulatr members (income over $\$ 140.000$ ). $\$ 175$; joint members (two individuals sharing the same household, who receive one subseription to PMLA but two copies of all other publications). add \$20) to dues caltegory of higherincome member: foreign members, same as regular members (use the American-dolfar equivalent to asecrtain the dues category). Membership applications are avaitable on request and at the MI.A Web site (http://www mla.org/)

The subscription price of $P M L A$ for libraries and other institutions is $\$ 123$. An institutional subscription including a bound volume at the end of the year is $\$ 265$, domestic and foreign. Agents deduct four percent as their fee. Single copies of the January, March, May, and October issues can be purchased for $\$ 12$ each; the September (Directory) issue is $\$ 50$; the November (Program) issue is $\$ 35$. The special millennium issue (Dec. 2000) is $\$ 35$.

Issues for the current year are available from the Member and Customer Services Office of the association (646 576-5151; membership@ mla.org). Claims for undelivered issues will be honored if they are received within six months of the publication date; thereafter the single-issue price will be charged

Volumes up to 1999 can be obtained on microfilm from Bell and Howell Information and Learning. 300 North Zeeb Road, PO Box 1346, Ann Arbor, MI 48106-1346 (800 521-0600; hilp://www.bellhowell infolearning.com/).

The office of publication and editorial offices are located at 26 Broadway, 3rd floor. New York, NY $10004-$ 1789 (646 576-5000: pmlasubmissions@mla.org).

All communications concerning membership. including change-of-address notifications, should be sent to the Member and Customer Services Office, MLA, 26 Broadway, 3rd floor, New York. NY 10004-1789 1646 576-5151: membership@mla.org). If a change of address also involves a change of institutional affiliation or a new e-mail address, that office should be informed of this fact at the same time.

Periodicals postage paid at New York, NY, and at additional mailing offices.

(1) 2001 by The Modern Language Association of America. All rights reserved. Printed in the United States of America.

Library of Congress Catalog Card Number 12-32040. United States Postal Service Number 449-660.

POSTMASTER: Send address changes to Member and Customer Services Office, MLA. 26 Broadway, 3rd floor. New York, NY 10004-1789. 
$16.5]$

\section{Contents}

I 293 A Statement of Editorial Policy

1294 Features in PMLA

I 294 Forthcoming in PMLA

I 297 Editor's Column: The Internet Sublime

1302 Beyond the Question of Authenticity: Witness and Testimony in the Fragments Controversy

Michael Bernard-Donals

I3I6 From Scipio to Nero to the Self: The Exemplary Politics of Stoicism in Garcilaso de la Vega's Elegies

E. C. Graf

I334 Keeping Her Distance: Cisneros, Dickinson, and the Politics of Private Enjoyment

GEOFFrEy SANBorN

I 349 The "Imitation David": Plagiarism, Collaboration, and the Making of a Gay Literary Tradition in David Leavitt's "The Term Paper Artist"

KenNeth BleEth and Julie Rivkin

\section{theorics and methodologies}

I 364 A Convenience of Marriage: Collaboration and Interdisciplinarity Linda Hutcheon and Michael Hutcheon

I 377 Authorship and Autography MichaEL NorTh

I386 A Phantom Discipline Rey CHow
Publications of the Modern Language AsSociation OF AMERICA Published six times a year ]

INDEXES

Vol.s. 1-50, 1935: 5I-60, 1945; 5I-79, 1964

Editor

Carlos J. Alonso

University of Pennsylvania

Managing Editor JUDY GOULDING

Assistant Editors

JOHN D. GOLBACH

Margit Longbrake ERIC WIRTH

Advertising Manager and

Submissions Associate

ANNABEL SCHNEIDER

Administrative Assistant ANGEL ButTS

\section{Editorial Board}

R. Howard BLOCH, 2003 Yale University

JOSEPH A. BOONE, 2003

University of Southern California

JAy Fliegelman, 2002

Stanford University

AVital Ronell. 2003 New York University

Mireille Rosello, 2002

Northwestern University

BRUCE R. SMITH, 2002

Georgetown University

Advisory Committee

DUDLEY ANDREW, 2004 Yale University

Paula Blank, 2004

College of William and Mary

Paul ANTHONy Bové, 2004

University of Pittsburgh, Pittsburgh

BEILA BrodzKI, 2002

Sarah Lawrence College

MARGaRet BRose, 2004

University of California, Santa Cruz

HEIDI BYRNES, 2002

Georgetown University

Kenneth S. Calmoon, 2004

University of Oregon

ANTHONY J. CASCARDI, 2003

University of Califomia, Berkeley

(continued) 


\section{Advisory Committee (continued)}

Michael Davidson, 2003 University of California, San Diego

Margreta de GRazia, 2003

University of Pennsylvania

Frances E. DOLAN, 2002

Miami University, Oxford

Madhu Dubey, 2003

Brown University

IAN DUNCAN, 2003

University of California, Berkeley

LYNN ENTERLINE, 2002

Vanderbilt University

Rosemary Geisdorfer FeaL, 2002 State University of New York, Buffalo

Catherine Gallagher, 2004

University of California, Berkeley HAZEL GOLD, 2002 Emory University

Farah Jasmine GrifFin, 2003 University of Pennsylvania

Phillip Brian Harper, 2002 New York University JOSEPH HARRIS, 2002 Duke University Julia HELi, 2004 University of Michigan, Ann Arbor Suvir Kaul, 2003

University of Illinois, Urbana

Deidre Shauna LynCh, 2004 Indiana University, Bloomington Amy Mandel.ker, 2004 Graduate Center, City University of New York

William D. PADEN, 2002 Northwestern University Donald E. PEAse, 2004 Dartmouth College

LESLIE W. RABINE, 2002

University of California, Irvine JOSEPH ROACH, 2003 Yale University

JACQUELINE JONES ROYSTER, 2002 Ohio State University, Columbus

Geoffrey Russom, 2003 Brown University

RICHARD L. STEIN, 2002 University of Oregon

KENNETH W. WARREN, 2003 University of Chicago LOUISE YELIN, 2003 State University of New York, Purchase the changing profession

I 396 Dr. Strange Media; or, How I Learned to Stop Worrying and Love Film Theory

D. N. RoDowick

I 405 The Library versus the Internet: Literary Studies under Siege? David S. Miall

I4 5 Who's Carving Up the Nineteenth Century? JFROME MCGANN

I 422 The Feel of Not to Feel It Charles J. RzEPKa

I 432 Our Puny Boundaries: Why the Craving for Carving Up the Nineteenth Century?

SUSAN J. WOLFSON

I 442 Forum

Earl R. Anjerson, Charlotete Berkowity, Robert' L. Carringir,

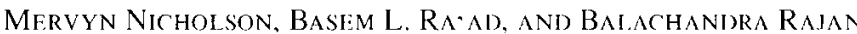

I45 I Forthcoming Meetings and Conferences of General InteresI

1453 Index of Advertisers

1470 Professional Notes and Comment

1470 Announcements

1476 Journal Notes

I 478 Meeling of the MLA Executive Council

I 5 I 6 Abstracts

I 5 I 8 Contents of Volume $116(2001)$ 